\title{
APPLICATION OF COMPETENCE MODELS IN PUBLIC SECTORS: REFLECTING THE DISRUPTION ERA
}

\author{
James Kalimanzila ${ }^{* * *) 1}$, Suryanto ${ }^{* * *}$ \\ ${ }^{*}$ Human Resource Officer, Ministry of Water, Government City \\ Maji Street, P.O. Box 456, Dodoma, Tanzania \\ ${ }^{* *}$ Human Resource Development Program, Post Graduate School, Universitas Airlangga \\ Jl. Airlangga 4-6, Surabaya 60286, Indonesia \\ ${ }^{* * *}$ Faculty of Psychology, Universitas Airlangga \\ Jl. Airlangga 4-6, Surabaya 60286, Indonesia
}

\begin{abstract}
The purpose of this study is to access and describe the application and development of competence models in public sectors particularly in the disrupting era. The development of technology, organization change and innovation have increased the necessity and application of competency models in public sectors based on hard and soft human skills. However, private sectors are doing well in applying competence models compared to public sectors. Moreover, public organization systems in the World have undergone many different reforms in order to handle and copy with issues happening in disrupting era. In this study, a qualitative research method was used based on explaining the concept of competence model, drawing insights from theories, reading different articles and publications. Furthermore, competency model is a very essential tool in human resource systems and public institutions practice because it guides and develops human resource skills, knowledge and behavioral that enable an employee to perform their job effective particularly in the challenging era. We would like to suggest that public institutions must apply competence models and create quick strategic basic reforms in order to undergo and copy with new changes or challenges like what private sectors do in dealing with disrupting issues.
\end{abstract}

Keywords: application, competence, competence model, public sector, disruption era

\begin{abstract}
Abstrak: Tujuan dari penelitian ini adalah untuk mengakses dan mendeskripsikan penerapan dan pengembangan model kompetensi di sektor publik khususnya di era disrupsi. Perkembangan teknologi, perubahan organisasi dan inovasi telah meningkatkan kebutuhan dan penerapan model kompetensi di sektor publik berbasis hard dan soft human skill. Namun, sektor swasta melakukan dengan baik dalam menerapkan model kompetensi dibandingkan dengan sektor publik. Apalagi, sistem organisasi publik di dunia telah mengalami banyak reformasi yang berbeda untuk menangani dan meniru isu-isu yang terjadi di era disrupsi. Dalam penelitian ini, metode penelitian kualitatif digunakan berdasarkan penjelasan konsep model kompetensi, menggali wawasan dari teori, membaca berbagai artikel dan publikasi. Lebih jauh lagi, model kompetensi adalah alat yang sangat penting dalam sistem sumber daya manusia dan praktik lembaga publik karena model ini memandu dan mengembangkan keterampilan, pengetahuan, dan perilaku sumber daya manusia yang memungkinkan seorang karyawan untuk melakukan pekerjaan mereka secara efektif terutama di era yang penuh tantangan. Kami ingin menyarankan bahwa lembaga publik harus menerapkan model kompetensi dan membuat reformasi dasar strategis yang cepat untuk menjalani dan meniru perubahan atau tantangan baru seperti yang dilakukan sektor swasta dalam menangani isu-isu yang mengganggu.
\end{abstract}

Kata kunci: aplikasi, kompetensi, model kompetensi, sektor publik, era disrupsi

\footnotetext{
${ }^{1}$ Corresponding author:

Email: kalimanzilajames@yahoo.com
} 


\section{INTRODUCTION}

Competency models are widely used in public offices for defining and assessing competencies within organizations in both hard and soft skills. Moreover, public managements systems in the world have experienced and undergone many great and major reforms mainly in the era 4.0. However, competency management has been implemented in public sectors in several countries in order to suit and fit these reforms and technological needs. Furthermore, lack and poor implementation of competent model in public institutions forced the researcher to choose this research topic based on Tanzania context. The purpose of this study is to demonstrate the application and implementation of competence models in public institutions particularly in the disrupting era.

Public organizations have been changing every day due to the development of technology, innovations, creativities and cultural changes, while the requirements for public sectors have been changing as well. However, it has been experienced some key principal challenges like lack of potential skills, knowledge, innovation and creativity. These tendencies generate a great need for developing competent style and models in public institutions. Recently, many people in the World are talking more about integrity, accountability, social maturity, professionalism, and need for innovation that is required in public institutions. Presently, new competency models have been adopted by several government institutions as a system for defining and demonstrating specific abilities, knowledge, behavior, skills and ensuring successful work delivery.

Furthermore, manpower is the key engine factor for economic success and development of any organization. Currently, the World lives in the era of globalized and digital economy that brings strong similarities, in time of huge explosion of information, changes and innovations. HR managers and experts think about how to find any competitive advantage that can enable their organization to differ from others and how to define, find and maintain those competencies that enable humans to adopt or copy with changes. However, private sector found an answer for these issues in Competency based management.

Competencies can be defined as visible and measurable attributes of a person that are causally related to enhanced employee performance and organizational development. They typically cover: - Knowledge gained through formal education, professional certifications, training, skills, abilities, work style and learned information used for the job.

Competency models may be a solution and applicable to all employees or workers in public institutions. Identifying employee competencies can contribute to improved organizational performance. They will be more effective when meet several critical standards, including linkage to, and leverage within an organization's human resource system. Moreover, Competency models are the key tools in HR systems and practice. Through the development of public administrations systems, the World have been subjected to major reforms and changes over the last 30 years and competency management has already been implemented in public institutions in many countries. This mean that, the root and application of competent model has its recognized and practical experiences in government organization once it is applied well and accordingly basing on government roles and principles.

Adisruptive era is referred as an era in which "technology and society are evolving faster than businesses can naturally adapt." New digital platforms are disrupting traditional markets overnight and globalization is rapidly changing customer needs and expectations.

Furthermore, there are four stages in classifying and understanding individual competencies in an organization as described below: - First is unconscious incompetence. This happen when an individual does not understand how to do something and does not necessarily recognize the insufficiency. Next is conscious incompetence. However, the individual does not understand or know how to do something, they recognize the deficit, and the value of a new skill in addressing the deficit. Third is conscious competence. Here an individual understands or knows how to do something. Nevertheless, demonstrating the skill or knowledge requires concentration. Lastly is unconscious competence. In this aspect an individual has so much practice with a skill that it has become "second nature" and can be performed easily. Types of competencies are: -Behavioral competencies, core competencies, functional competencies, Management competencies, organizational competencies and technical competencies. 
Previous studies are identified as all the previous researches which have tackled the topic in which the researcher is digging through discussion and studying. In accomplishing this study, the researcher has used many previous researches in order to demonstrate the validity and to generate more understanding of the topic. The following are the few previous research that has been applied in this research:

In public sectors, competence models determine and demonstrates the difference between what the business basically expects (by declaring in internal policy) and between what is really required from the workers or employees. Competency models are arisen and created from competencies - they are a collection of abilities, qualities, capacities and skills of the staff needed for successful performance of their positions.

Likewise, public institutions take more attention in administrative competencies because the quality of managerial work strongly influences the performance and success of an organization. Therefore, the group of the core competencies creates a competency model. In another side, Competency model designates a specific combination of skills, knowledge, and personality characteristics that are necessary for effective performance of duties in the organization (Kubes et al. 2004).

Competency Models demonstrate and define what it means to be a successful human resource professional across the performance scale of the entire organization. The competency model and the resources developed based on the model provide the foundation for talent management throughout the human resource development for both public and private sectors.

Moreover, the identification of competencies in the community led to the creation of competency model which is futured by employees and job positions. In public sectors, competency models are used in many areas such as recruiting, design training and development programs. It is a key tool in evaluating the employees, career planning and talent management. Kubes et al. (2004) states that the final list of competencies encompassed in the competency model is sometimes a big shock for an organization.

Furthermore, there basic steps required to create competency models in public organizations thus are: -collecting information about job roles, interviewing experts to discover current critical competencies and how they envision their roles changing in the future, identifying high performer behaviors, creating, reviewing and delivering the competency model. Once the competency model has been created, the final step involves communicating how the organization plans to use the competency model to support initiatives such as recruiting as well as performance management.

The purpose of this research was to demonstrate the application and implementation of competence models in public organizations particularly in the globalized and disrupting era. Competency models are widely used in public institutions for defining and assessing competencies within organizations in both hard and soft skills. Moreover, public managements systems in the global have undergone many basic reforms due to the development of digital, technology as well as the increase of global interactions. However, competency management has been implemented in public organizations in several nations in order to suit and fit these reforms and technological needs but the implementation of competent model still very low and need more emphases in public organization because most of government issues do not think on competition and quality.

The problem of this study is lack and insufficient application of competence model in public organizations particularly in disrupting and technological era. This situation has removed or reduce the ability of government institutions to compete with private institutions because of lack of employee competent model application. The scope of this paper is based in public sectors or institutions. Many government organizations do not recognize or demonstrate competent models to its employee compared to private sector.

\section{METHODS}

This study applied qualitative research by collecting data using different qualitative methods like collecting data from publications, social media, articles and books. This method named as document analysis. According to (Corbin \& Strauss, 2008; Bowen, 2009) document analysis can be defined as a systematic procedure to examine or evaluate document that can be taken from both printed and electronic materials. Similar with some other methods of research, document analysis can stand alone as a single research method. However, exactly 
similar with other methods of research, it is important to remember that document analysis also requires repeated review, examination, and interpretation of the data to get the exact meaning and empirical knowledge of the construct study (Frey, 2018).

In this study, a qualitative research method was used based on explaining the concept of competence model, drawing insights from the literature and theories. This chapter explains the methodology applied in the study when collecting data and findings. It presents the research design, data collection methods, the study area, study population, and scope of the study.

Moreover, with regard to the methodological procedure adopted, this research is classified as descriptive, exploratory, and bibliographic. This research is considered as exploratory in nature because it aims to provide the researcher a greater familiarity with the problem to be studied, and will be used since it is intended to define the situation with greater precision and to identify relevant courses of action or to obtain additional data before starting a new approach or style.

The study bases on application of competent model in public institutions. Moreover, this research based and focused in public organization in Tanzania by investigating and demonstrating the positivity of applying competent model in public institutions. Likewise, the research based of differentiating the private and government institutions on competence development, application and its results.

This research is qualitative in nature because it describes and explain the situation of competent model in public organizations in Tanzania. Moreover, the researcher has used both secondary data (reading articles, papers, publications and books) and primary data which used self-administered surveys, interviews, and field observation because the researcher is also working in government institutions and its agencies.

Research material is referred to all tangible materials or products that used related to the research. In this research various materials were used such as, paper, pen, computer. This research will focus on secondary data source such as getting information through public sectors website: policy documents, human resource development books, and career development publications. Furthermore, this chapter discusses the methods used in this study for collecting data. The methods helped the researchers to collect as many data as possible which in turn helped the researchers to analyses the current situation of Competence Model in Public Sectors.

This research has used qualitative data analysis method in describing and explaining the fact and situation of employee competent in government organization basing in Tanzania perspective. The researcher used Qualitative data analysis method simply because it does not need a lot of time and scientific survey it needs only fact and explanation.

The diagram (Figure 1) demonstrates the key aspects and components of competence. Moreover, the diagram shows the dimensions of competence as well the application and its use of competent model in an organization. The research was conducted by using the descriptive and analytical research designs where qualitative methods was used in the collection and analyzing data. Also, survey research design was applied as the researcher seeks to study the situation and implementation of competence model in public sectors.

According to Industrial Development Organization of United Nation (2002), Competences are collection of personal skills, knowledge and personal specifications which can make competence in people without having practices and related specialized capabilities. Moreover, competency is sometimes is described as thought of being shown in action in a situation and context that might be different the next time a person has to act. In emergencies, competent people may react to a situation following behaviors they have previously found to succeed. To be competent a person would need to be able to interpret the situation in the context and to have a repertoire of possible actions to take and have trained in the possible actions in the repertoire, if this is relevant. Regardless of training, competency would grow up through experience and the extent of an individual's capacity to learn, copy and adapt. However, some researchers have found that it is not easy to assess competencies and competence development. 


\section{Competence components}

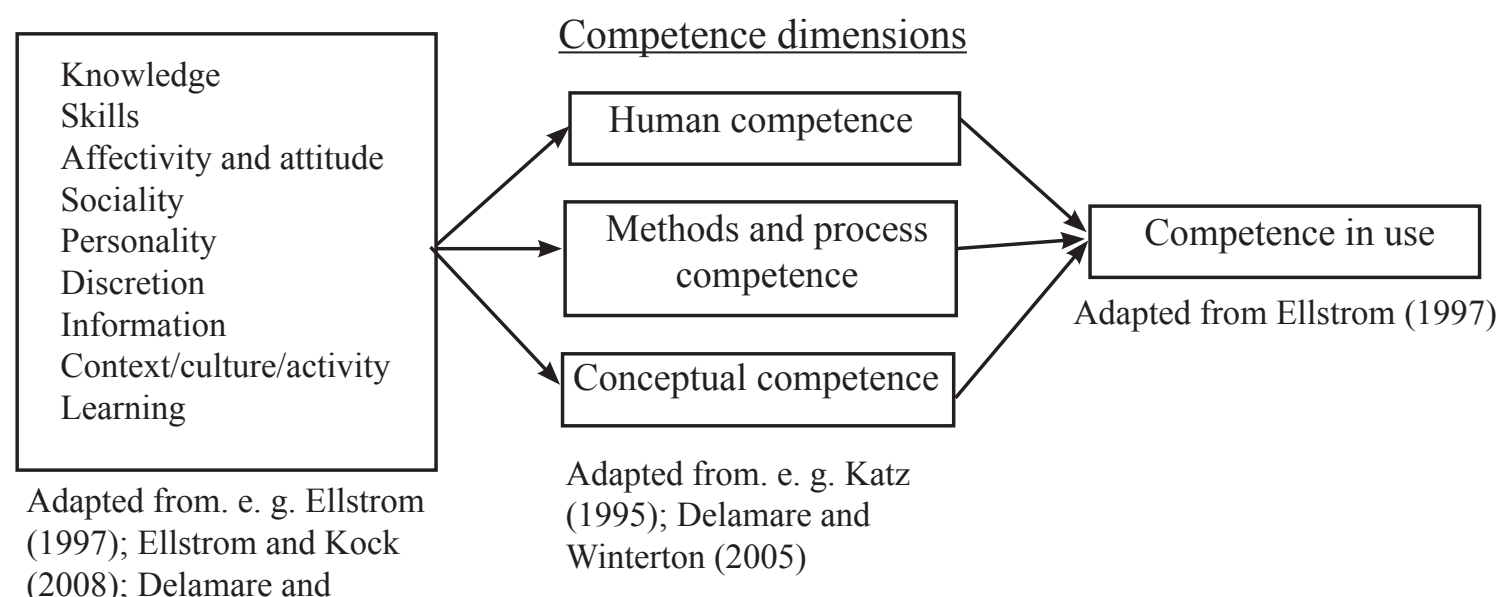

(2008); Delamare and

Winterton (2005)

Winterton (2005)

Figure 1. Research framework

A hypothesis is an assumption, an idea that is proposed for the sake of argument so that it can be tested to see if it might be true. Moreover, in this research the researcher has used working or research hypothesis simply because it demonstrates the specific, clear prediction about the possible outcome of a scientific research study based on specific factors of the population. In this study the research population was employees in government institutions.

\section{RESULTS}

The study demonstrated that, public sectors in developing countries have not been able to progress a modern and standard form of competency administration over the past decade while private sectors seems to do better on competency development particularly in the disrupting era. This mean that the focus of private organization is to be able to compete and win global business which have many disrupting and competitive style while government organization remain on result aspect only. Hence, it reduces the application of competent model.

Moreover, the development of technology, innovation and creativity have increased the need and necessity of competency models in public sectors around the World. In additional to that, organization changes, culture changes and environment changes have demanded new skills, knowledge and individual behaviors in order to save and make public sectors more comparatives in economy. Therefore, public sectors are in great changes and applying new and modern competency models which can suit with the current situations. Likewise, this study demonstrates that many competency models in public sectors bases much in competency management particularly in HR processes of recruitment and selection, training and development, succession planning, and career guidance while leaving behind strategic and leadership competencies.

Besides, this research shows that the use of competencies for performance evaluation and remuneration purposes remains limited in public sectors. However, each country confirms the added value of introducing competency management in their central government, going from creating a culture of self-development to improving a government's competitiveness as well as global business competition.

This study also shows that, the competency-based approach also supports the efforts to meet the challenges associated with modern and strategic HR management in public organization particularly in the disrupting era. Moreover, it is expected that when civil servants apply their competencies to their work, the result is effective performance, increase of production, high quality of products and improvement on service quality.

The result shows that, todays many governments have undergone some basic reforms in order to suit with organization changes, globalization and new technology which needs new skills, knowledge and ability. This aims to change the traditional personnel management into strategic human resource management that allow and accept global integration and more application of skills, knowledge and skills which increases selfcompetent model. 
Although it continues to evolve, competency management is now fairly mature and well-integrated into the governments' HR system. The level of maturity of competency management, however, is associated with the three dimensions of integration: vertical integration, horizontal integration, and implementation in the organization. Although all countries are committed to these three dimensions of integration, few can report a holistic approach to competency management.

According to (Gaul, 2014; Innosight, 2014), eighty-five (85) percent of people believe that their organization needed to adapt new competency models because of technological change, global integration, knowledge development, culture and disruptive change from different countries. However few people are confident that public sectors do not need quick and modern competencies. When government organization succeed to do this, they will afford to survive and compete in times of disruptive change. Moreover, the study aimed to analyze the application, effectiveness and needs of competence models in public institutions.

Disruptive change "Perhaps the greatest challenge business leaders face today is how to stay competitive amid constant turbulence and disruption." (Kotter, 2012). McCann et al. (2009) Public institutions need to adopt new ways in order to copy with new changes. Therefore, public sectors need new and effective competency model by imposing and improving their people's or worker's knowledge, skills and ability. This will increase organization competitiveness and well as creativity and innovation.

However, the identification and assessment of competencies in public sectors, as well as the development of competency-based management frameworks to support activities such as 'gap analysis', recruitment, learning and other key human resource processes, all reflect an acknowledgement of competent model by public organizations success in the modern workplace and disrupting era (Bonder et al. 2011).

In this disrupting era public organizations need to implement effectively competent model. Moreover, any high performing institution is connected with high the performance of employees due to proper selection of talented employees who are able to carry out the organization's vision, mission and meet the targets of the organization. In this era many things have changed dramatically therefore there is a great need to change some basic principles of managing human resources by adopting or implementing some potential competent model that will increase the rate of business competition as well as increase production.

Furthermore, the results of this study show that human being and government are not static, therefore the increase of global interaction, globalization and development of technology has increased many leaderships and working styles. Hence, every organization need to emphases their workers to apply their competent model effectively in order to be able to compete and survive in this competitive, disrupting and globalized era.

\section{Managerial Implications}

Managerial Implications abridge what the results mean in terms of actions. This mean that, Managerial Implications compare the results to the action standard, and indicate what action or even non-action should be taken in response. The managerial implication of this research bases on the following key aspects. The development of technology and globalization has changed and brough many management styles and changes. Hence, the government or public institutions need to copy with new and modern technology and knowledge so to be able to compete in a global market and international business competition. There, there is a great need to apply competence model in solving these challenges and copying with the new changes. The implication of competence model is demonstrated also in advancing and making government organization more competitive with high production and quality services through applying and providing skills, knowledge and ability.

Furthermore, the managerial implication of this research is observed on its aims that bases on accessing and describing the application and development of competence models in public sectors particularly in the disrupting era. The development of technology, organization change has increased the necessity of competency models in public sectors based on soft human skill. 


\section{CONCLUSIONS AND RECOMMENDATIONS}

\section{Conclusions}

By concluding, the development of technology and increase of global integration of human resource has increased and demonstrated the necessity of implementing competency models in public organization, today competent models are key tools in human resource management in any organization development. However, in the disrupting era there some factors which have increased the needs and application of competence models in both public and private sectors such as development of technology, environment change, culture change, as well as the development of technology. It is true and open clear that, public sectors are not doing well in applying effective, updated and modified competency models when handling different challenges which are happening in the disrupting era. In another hand private organization are doing better in implementing and using competent models. Application of skills and maturity competencies helps organization in handling some basic function such as recruitment, employee selection, person emolument, preparation of seniority list, promotion and training.

Furthermore, Private sector has dominated the use and proper application of competence model almost over the last 20 years compared to government sectors. In this research the researcher has demonstrated on how government organization has already taken competency agenda into public sectors and they observe positive results in effective and rules-based recruiting process.

\section{Recommendations}

Therefore, this research recommends that, public sectors must apply and implement modern and valid competency models to their employees in order to copy and deal with all uncertainties and challenges which are happening in disrupting era. This will help them to get skilled and knowledgeable employees, hence it will improve and increase organization innovation, creativity and global economic competition. Likewise, the research like to recommend that, public sectors must change and update its policies, guidelines and regulations so that they can suit and copy with the new and upcoming situations and issues that are happening in the disrupting era such as change of technology, organization change, culture change or cross-cultural issues, innovation, creativity and global warming effect. When the government shape and change on result focus only, employee or work outlook will also change because they will look on creativity and global competition too. This will be done through paving the way to them by provide training and development to them. Hence their competent model will be improved and adhered too. The development of soft skills always improves and increase organization production this mean that when government organization decide to emphases more on the application of competent model the quality of service will increase and also organization will increase its productions.

\section{REFERENCES}

Bonder A, Bouchard CD, Bellemare G. 2011. Competency-based management - an integrated approach to human resource management in the Canadian public sector. Public Personnel Management 40(1):1-10. https://doi. org/10.1177/009102601104000101

Bowen GA. 2009. Document analysis as a qualitative research method. Qualitative research journal 9(2):27-40. https://doi.org/10.3316/ QRJ0902027

Corbin J, Strauss A. 2008. Basic of Qualitative Research: Techniques and Procedures for Developing Grounded Theory. 3rd Ed. Thousand Oaks: Sage Publications. https://doi. org/10.4135/9781452230153

Delamare, Winterton. 2005. Typology of Knowledge, Skills and Competences: Clarification of The Concept and Prototype. Luxembourg: Office for Official Publications of the European Communities.

Ellström P. 1997. The many meanings of occupational competence and qualification. Journal of European Industrial Training 21(6/7): 266-273. https://doi.org/10.1108/03090599710171567

Ellstrom, Kock. 2008. Competence development in the workplace: concepts, strategies and effects. Education Research Institute 9(1): 5-20. https:// doi.org/10.1007/BF03025821

Frey BB. 2018. The SAGE Encyclopedia of Educational Research, Measurement, and Evaluation. Thousand Oaks: Sage Publications. https://doi. 
org/10.4135/9781506326139

Gaul P. 2014. Organizations lack planning and tools to deal with disruptive change. Talent Development 8:24.

Innosight. 2014. The strategy confidence gap. Results from our survey on strategic readiness and disruptive change. https://www.innosight.com/ wp-content.

Kotter JP. 2012. Accelerate! How the most innovative companies capitalize on today's rapid fire strategic challenges and still make their numbers. Harvard Business Review 11:44-58.
Kubeš M, Spillerova D, Kurnicky R. 2004. Manazerske kompetence-zpusobilostivyjimecnychmanazeru [Competences of Managers-Skills of Excellent Managers]. Prague: Grada Publishing.

McCann J, Selsky J, Lee J. 2009. Building agility, resilience and performance in turbulent environments. People \& Strategy 32(3):44-51.

OECD. 2007. OECD Environmental Performance Reviews OECD Environmental Performance Reviews: New Zealand 2007. Paris: OECD Publishing. 